\title{
The relationship between inflation and unemployment: a critique of Friedman and Phelps*
}

\author{
Louis-Philippe Rochon \\ Laurentian University, Sudbury, ON, Canada \\ Sergio Rossi \\ University of Fribourg, Switzerland
}

The 'natural rate of unemployment' was not an important part of Friedman's presidential address, although it is what the paper is remembered for. On the 50th anniversary of the paper, we argue that there is no 'natural rate of unemployment', and that the relation between inflation and unemployment is not the one assumed by Friedman or neoclassical theory. In Section 2 we present the conventional framework in which the Phillips curve is drawn by neoclassical economists. It emphasizes the exogenous nature of money, as well as the assumption that (a large part of) unemployment has to do with workers' trade-off between paid work and leisure time (in a utility maximization perspective). Section 3 explains that the neoclassical framework is flawed, because money is endogenous and unemployment is not simply an outcome of workers' choices with regard to the observed 'equilibrium' wage level. This section points out that inflation cannot be controlled with an interest-rate policy and that unemployment is the result of a lack of effective demand (hence it is involuntary). Section 4 provides two alternative macroeconomic analyses, one where inflation as well as unemployment are explained by the disorderly working of the banking system and another where conflict in the functional distribution of income within a monetary economy of production dominates. The conclusion offers some policy-oriented remarks as regards contemporary fiscal and monetary policies that a variety of countries have been adopting in their (largely ineffective) attempt to emerge from the crisis that erupted in 2008 at the global level - whose negative consequences still affect a relevant part of the world population.

Keywords: Friedman, Post-Keynesian, NAIRU, conflict inflation, hysteresis

JEL codes: $B 22, E 02, E 12, E 52, E 58$

\section{INTRODUCTION}

2018 marks the 50th anniversary of both Friedman's (1968) and Phelps's (1968; see also 1967) influential papers, which have not only impacted the course of economic theory, but also influenced the conduct of economic policy, in particular how policy-makers deal with inflation and unemployment. In fact, the American Economic

* An earlier version of this paper was presented on 27 July 2017 in Quito, Ecuador. The authors would like to thank Eugenia Correa, Malcolm Sawyer, Mario Seccareccia and Jan Toporowski for their useful comments. The usual disclaimers apply. 
Review (2011) ranked Friedman's 1968 paper as one of the top 20 most influential papers in economics.

Friedman's 1968 paper, which represents his presidential address to the American Economic Association on 29 December 1967, was primarily a reply to Keynes and Keynesians who came to believe monetary policy was inefficient in generating real economic growth during depressed times. While describing his approach as 'reactionary', the purpose of Friedman's 1968 paper is clear: monetary policy is in fact wholly relevant even in depressed times, and Friedman sets out the conditions under which it is. According to the author, " $[\mathrm{t}] \mathrm{he}$ Great Contraction is tragic testimony to the power of monetary policy not, as Keynes and so many of his contemporaries believed, evidence of its impotence' (Friedman 1968, p. 3). In this sense, the purpose of his presidential address is first and foremost to discuss the importance of monetary policy, with the discussion of a natural rate of unemployment and the Phillips curve being somewhat secondary. Indeed, as Forder (2018) argues, Friedman was first and foremost interested in discussing rules vs discretion with respect to monetary policy, and the discussion of a Phillips curve was 'far from his mind'.

Despite Friedman's heavy emphasis on monetary policy (the title of his 1968 paper as well as the titles of each subsection of it emphasize monetary policy), the Phillips curve, both in the short and the long run, is nevertheless raised, and the idea of a long-run natural rate of unemployment is born: it is for these arguments that this paper has been remembered, rightly or wrongly. For instance, in a recent paper, Thirlwall (2018, p. 12) explains how '[r]esearch on the Phillips curve took another sharp turn in 1968 when Milton Friedman brought to the fore the concept of the natural rate of unemployment, and vehemently denied that there is a long-term trade-off between unemployment and inflation'. Friedman himself (see Friedman and Friedman 1998, p. 230) contributed to this myth-building by advocating some three decades later that he "introduced the concept of a "natural rate of unemployment" to which the level of unemployment would tend whatever the rate of inflation, once economic agents came to expect that rate of inflation. To keep unemployment below the natural level requires not simply inflation, but accelerating inflation'.

Friedman's rejection of a long-run relationship between inflation and unemployment provided agents are correctly informed and behave rationally - still features prominently in the policy mix today, and continues to influence a new generation of young scholars and policy-makers. For instance, 50 years later, in an 18 January 2017 speech to the Commonwealth Club in San Francisco, the US Federal Reserve Governor, Janet Yellen, explained that '[i]t's important to try to estimate the unemployment rate that is equivalent to maximum employment because persistently operating below it pushes inflation higher'. However, as cogently argued by Forder (2010), the argument predates the late 1960s with regard to expectations theory.

The Friedman-Phelps narrative carries important implications for policy. While economists are in general agreement over the need to control for unemployment and inflation (a sentiment echoed in the opening sentence in Friedman 1968), the profession is rather split when it comes to the kind of public intervention or the role of fiscal policy. In contrast to the established Post-Keynesian tradition, orthodox (neoclassical) economists argue that the public sector must provide just the right incentives, in order to influence agents' behaviour such that their transactions in the marketplace give rise to price stability and full employment - independently of how these policy goals are defined conceptually and measured in practice.

With respect to monetary policy, however, central-bank interventions must aim at price stability, whilst structural reforms (should) make sure that the labour market is at its alleged 'natural' equilibrium, defined as the equilibrium between supply and demand. Under these conditions, state intervention can have no impact whatsoever - and there would exist a 
so-called 'natural rate of unemployment', defined as the combination of frictional and structural unemployment that results from the natural dynamics of any capitalist system.

The existence of this so-called 'natural rate of unemployment', however, is problematic, and this paper explains, from a critical and heterodox perspective, that, in fact, there is no 'natural rate of unemployment' and that the relation between inflation and unemployment cannot be understood by simply referring to the so-called Phillips curve, both in its short-run form and particularly in its vertical (long-run) form.

The purpose of this paper is twofold. First, it addresses the issue of endogenous money as a critique of Friedman's assumed exogenous money supply, which is at the core of his 1968 contribution. Second, with this critique in hand, we then attempt to show the irrelevance of the natural rate of unemployment. To do this, two heterodox approaches to inflation are proposed.

The paper is structured as follows. Section 2 presents the conventional framework in which the Phillips curve has been drawn by neoclassical economists. It points out in particular the exogenous nature of money supposed by these authors as well as their assumption that (a large part of) unemployment has to do with workers' trade-off between paid work and leisure time (in a utility maximization perspective). Section 3 explains why the neoclassical framework is flawed: money is in fact endogenous and unemployment is not simply an outcome of workers' choices - with regard to the observed 'equilibrium' wage level. This section points out that inflation cannot be controlled with an interest-rate policy and that unemployment is mainly the result of a lack of effective demand (hence it is involuntary).

Section 4 moves from there to address the existence of a natural rate of unemployment directly, by providing a fundamentally different macroeconomic analysis, wholly consistent with the Post-Keynesian approach. We argue that endogenous money, a rethinking of the causes of inflation, as well as hysteresis render the Friedman-Phelps view of macroeconomics obsolete. In our attempt to demonstrate this, we will rely on two heterodox explanations of inflation: (i) a conflict-inflation model, and (ii) an approach where inflation is explained by the disorderly working of the banking system in a monetary production economy. We conclude that Keynes's approach is better suited than Friedman's and Phelps's to understand, and hence to address, both inflation and the involuntary unemployment that coexist in our economic systems. The conclusion, in Section 5, offers some policy-oriented remarks as regards contemporary fiscal and monetary policies that a variety of countries have been adopting in their largely ineffective attempt to emerge from the crisis that erupted in 2008 at the global level - whose negative consequences still affect a relevant part of the world population.

\section{THE EXPECTATIONS-AUGMENTED PHILLIPS CURVE}

The Friedman-Phelps view, as embodied in Friedman (1968), rests on the following three elements:

1. an exogenous money supply; ${ }^{1}$

2. a theory of inflation dictated by excess demand, as a 'monetary phenomenon';

1. We acknowledge that the exogenous nature of the money supply has been replaced today by a (somewhat) endogenous supply, as in New Consensus models. In these models, however, inflation is still seen as a result of excess demand forces. This amounts to a variation of the Friedman view, and not an abandonment of it. In this sense, we agree with Lavoie (2004, p.16), who has called it 'new wine in an old bottle'. 
3. a long-run or natural level of unemployment independent of short-run disturbances.

The expectations-augmented Phillips curve proposed by Friedman (1968) was an attempt to explain that if 'there is always a temporary trade-off between inflation and unemployment[,] there is no permanent trade-off. The temporary trade-off comes not from inflation per se, but from unanticipated inflation, which generally means, from a rising rate of inflation' (Friedman 1968, p. 11). This argument is just as much a statement on the Phillips curve as it is about the conduct of monetary policy. It is indeed instrumental in order for orthodox economists to explain why monetary policy should focus on price stability (on the goods market) rather than trying to affect the (un)employment level, since the latter does not depend on nominal magnitudes such as the money supply or the policy rate of interest. Assuming the neoclassical dichotomy between the so-called 'real' and monetary sectors, and positing that agents have adaptive expectations, Friedman (1968, p. 13) notably argued that '[o]ur economic system will work best when producers and consumers, employers and employees, can proceed with full confidence that the average level of prices will behave in a known way in the future - preferably that it will be highly stable'.

The above argument echoes Phelps's (1967, p. 256, emphases in the original) earlier argument that 'a more inflationary policy permits a transitory increase of the employment level in the present at the expense of a (permanently) higher inflation and higher interest rates in the future steady state'. According to this argument, the expected rate of inflation increases whenever the central bank intervenes to support employment. As a result of this policy, agents expect a higher rate of interest in order to reduce the (expected) inflation rate in the future. In turn, these expectations influence agents' behaviour as if nominal magnitudes were already at their future (expected) level, thereby making any monetary policy ineffective in its attempt to increase the employment level. This contrasts with the original (Keynesian) Phillips curve, where there exists a trade-off between inflation and unemployment in the short run (see Phillips 1958). Graphically, this amounts to saying that

the Phillips curve, in terms of percentage price increase (or wage increase), shifts uniformly upward by one percentage point with every one point increase of the expected percentage price increase (or expected wage increase). Then the equilibrium unemployment rate - the rate at which actual and expected price increases (or wage increases) are equal - is independent of the rate of inflation. (Phelps 1968, p. 682, emphasis in the original)

If so, then, in the long run, the Phillips curve is a vertical line in the inflation/unemployment space, and its vertical position depends on the so-called 'non-accelerating inflation rate of unemployment' (NAIRU), also known as the 'natural rate of unemployment'.

Considered from a broader perspective, this approach fits with the neutrality-of-money view that Friedman largely contributed to spreading across the economics profession (see Rossi 2018). Notably, it assumes that the central bank is 'always and everywhere' in a position to determine the money supply, which monetarists à la Friedman imagine is an exogenous magnitude within the economic system. This is why Friedman (1987, p. 17, emphasis in the original) famously maintained that 'inflation is always and everywhere a monetary phenomenon in the sense that it is and can be produced only by a more rapid increase in the quantity of money than in output'. In this perspective, the central bank is responsible for inflation, as it controls the money supply directly (with regard to centralbank 'high-powered' money) and indirectly (through the so-called 'money multiplier'). 
The assumption that money is neutral with regard to 'real' magnitudes, such as the rate of unemployment, corroborates the orthodox hypothesis that unemployment depends on the utility maximization process of each potential worker, hence that it is voluntary and therefore influenced by a variety of public incentives (notably the amount and duration of unemployment benefits). In this perspective, people maximize their utility, deciding whether it is worth suffering from a 'negative utility' by working a given number of hours a day in order to earn an income which they will (partly) spend on the goods market, to obtain a positive utility through consumption. The individual's decision depends therefore on the wage level they can get on the labour market, which, according to Friedman (1972), is determined in real terms as a result of agents' inflationary expectations (see above).

\section{SOME MAJOR FLAWS OF NEOCLASSICAL ECONOMICS}

The framework within which Friedman (1968) and Phelps $(1967 ; 1968)$ elaborate their analysis is flawed on both conceptual and methodological grounds. First, inflation is a loss in money's purchasing power, which gives rise to an increase in prices but cannot be measured by the rate of change in some price level, because - apart from inflation there are other factors of price increases (in the next section, we discuss two heterodox approaches to the causes of inflation) (see Cencini and Rossi 2016, pp. 178-179). Second and more importantly, inflation cannot be explained by assuming an exogenous money supply (as monetarists do). In fact, money is endogenous and depends on the needs of trade. Indeed, as Moore (1988, p. 46) writes, money is 'credit-driven and demand-determined', a statement at the core of Post-Keynesian macroeconomics. This means that central banks cannot steer the money supply using the so-called 'money multiplier', because the amount of money is an outcome that depends on the banks' willingness to provide credit to economic agents, whose willingness to borrow depends on effective demand more than on banks' rates of interest (a price administered by the national central bank). In this sense, inflation is neither a monetary nor a monetarypolicy phenomenon (see the next section for a discussion of the causes of inflation).

So far, two of the three core Friedman-Phelps principles outlined in the previous section have been disproven. Indeed, we would argue that, in themselves, these should discredit Friedman's discussion of a natural rate of unemployment, which itself is made to depend on the exogeneity of the money supply, which is an essential component of Friedman's theory of a long-run Phillips curve. Indeed, Friedman develops his views on a natural rate within the framework of the conduct of monetary policy and an exogenous money supply. Without it, he is unable to show how this long-run relationship between inflation and unemployment exists. Hence disproving the exogeneity of the money supply should be sufficient to disprove Friedman's approach. Yet more contemporary mainstream models, such as New Consensus models, have abandoned exogenous money but have retained a natural rate of unemployment. In his discussion of New Consensus models, Lavoie (2014, p. 541) argues that

a negative discrepancy between the market and the natural rate of interest opens up an output gap that leads to an acceleration of the inflation rate, supported by growth in the money supply. This is akin to the accelerationist thesis and the vertical Phillips curve, based on the natural rate of unemployment or the non-accelerating inflation rate of unemployment (NAIRU).

In other words, the endogeneity of money is not sufficient to invalidate the natural rate of unemployment, and the next section addresses this argument. 
Before we do this, however, it is worth mentioning that it may seem odd that Friedman's discussion of the natural rate of unemployment is done within a paper devoted to monetary policy, the exogeneity of money, and the natural rate of interest. We argue, however, that this is no accident, as Friedman's view of labour markets and the subsequent development of a natural unemployment rate are inspired by Wicksell's theory of interest rates: if there exist two interest rates (a market rate and a natural rate), Friedman (1968, pp. 7-8) contends that there must also exist two unemployment rates: a market (short-term) rate and a natural (long-term) rate: 'The preceding analysis of interest rates can be translated fairly directly into Wicksellian terms ... . This analysis has its close counterpart in the employment market'.

Yet Friedman's mimicry of Wicksell's work remains odd, given the latter's views on pure-credit economies and money's endogeneity. Yet Wicksell's notion of a natural rate of interest is both unobserved and unobservable, something oddly enough Friedman acknowledges: 'One problem is that it [the policy-maker] cannot know what the "natural" rate is. Unfortunately, we have as yet devised no method to estimate accurately and readily the natural rate of either interest or unemployment' (Friedman 1968, p. 10). Despite this criticism, Friedman moves forward with his development of a natural rate of unemployment, assuming it too can be 'accurately' measured.

The next section will deal with the expectations-augmented Phillips curve and the natural rate of unemployment directly. In order to explain how it is irrelevant, we will rely on two heterodox approaches, each providing a different explanation of inflation. The first approach, associated with Bernard Schmitt and quantum macroeconomic theory (or the Dijon-Fribourg school), rests on the book-entry nature of money and its association to production through the payment of wages. The second approach is a conflict-inflation theory with hysteresis effects. We argue that each of these approaches on their own casts serious doubts on the existence of a natural rate of interest.

\section{POST-KEYNESIAN THEORIES OF INFLATION}

Let us take up the challenge of explaining inflation in an endogenous-money system where bank credit is the independent variable with regard to the money supply and its relation to produced output. As regards unemployment, the neoclassical analysis is also largely wrong, in so far as it maintains that unemployment can be explained by the behaviour of potential workers in respect of their trade-off between leisure time (which provides a positive utility to them) and working time (which brings a negative utility to them) and available unemployment benefits. In fact, the vast majority of unemployed people are willing and ready to work at the going wage level: the problem is that no firm will hire them, considering the lack of effective demand on the market for produced goods and services (see Keynes 1936). Therefore, it is not by reducing the real wage level - as a result of a higher unemployment - that firms will eventually hire more people: the reduction in real wages elicits a loss in households' purchasing power, thereby leading to a further reduction of demand on the product market. In turn, this leads to a reduction in firms' profits that can induce them to further reduce employment, in a vicious circle leading to an economic recession (or a depression).

To be sure, Keynes's (1936) explanation of involuntary unemployment is a more appropriate argument than the neoclassical view to understand the origin of such a pathology in a monetary economy of production. Before turning to this explanation, it is worth pointing out that the relation between inflation and unemployment put forward by Phelps $(1967 ; 1968)$ and Friedman (1968) does not consider the (endogenous) nature 
of money and the (involuntary) essence of unemployment, which are clearly two hallmarks of contemporary capitalist systems. As the foundations of their analysis are flawed, one cannot be surprised to notice therefore that their policy proposals are not in a position to deliver the promised results. An entirely different analytical framework is required, one that considers money's endogeneity and involuntary unemployment - two features that are at centre stage in different strands of heterodox economics, particularly in monetary circuit theory and the monetary theory of production (see Graziani 2003).

\subsection{The quantum macroeconomic approach: inflation and unemployment are structural-monetary disorders}

According to this first Post-Keynesian approach, inflation and unemployment stem from the disorderly working of the banking system in our monetary economies of production. As such, they are not the result of agents' forms of behaviour, as maintained by Phelps (1967; 1968) and Friedman (1968) among others, but the mark of a structural-monetary flaw (see Bailly et al. 2017).

In an endogenous-money system - that is, in the real world - banks have the extraordinary power to issue money from zero, by entering into their ledgers the result of a credit line, which they may provide to any kinds of agents, including banks themselves. As inflation is a loss in money's purchasing power, one needs a monetary theory of production to be able to understand this pathology (which is the first analytical step necessary to address this pathology correctly). Indeed, if there is nothing to purchase, because no output has been produced, money has no purchasing power at all (assuming away all assets, which are also directly or indirectly linked to some produced output). Money and output must therefore be associated from the beginning of the analysis, which means on the labour market (rather than on the goods market, as neoclassical economists have been doing). If so, then any emission of money that banks carry out independently of production has an inflationary outcome, since it increases the amount of bank deposits without making an equivalent, simultaneous contribution to produced output. The fact that this inflation is not revealed by changes in the price level on the goods market (such as the consumer price index) - because banks' credit lines are used to carry out financial transactions - is not enough to ignore these operations and the inflationary pressures they give rise to in the economic system as a whole (see Rossi 2015).

This is so because the volume of bank deposits resulting from what Werner (2012, p. 29) labels 'non-GDP-based transactions' induces a deflationary pressure on the market for produced goods and services: deposit-holders are led to spend on financial markets - in light of the observed increasing prices on this market - what they would otherwise have spent on the product market. This point deserves consideration also in regard to the fact that what mainstream economists have called the 'law of economics' - namely, the 'law' of supply and demand - works in the opposite direction when it refers to financial markets. As a matter of fact, when the price of a financial asset increases, agents are led to purchase it, as they expect this price to increase further and thereby to earn a profit by speculating on the relevant market. By contrast, when the price of a good increases, this usually reduces the demand for it (unless it is a luxury good, which may play the role of a status symbol).

With regard to unemployment, this is therefore clearly the result of a lack of demand on the market for produced goods and services. Any further downward pressure on wages, resulting from the 'law of economics' on the labour market, is then unable to induce an increase in labour demand by firms, as the latter expect a further reduction 
in their sales, owing to the reduced purchasing power of households and their negative expectations in light of the (for them worrying) labour market conditions.

All in all, inflation and unemployment are intertwined as a result of banks' behaviour on the credit market. When commercial banks provide credit lines to carry out 'non-GDP-based transactions' (Werner 2012, p. 29), they inflate the volume of bank deposits with no original purchasing power. This is instrumental in order for asset prices to inflate and translate into involuntary unemployment when deposit-holders decide to purchase (real or financial) assets (whose prices increase as a result of this inflationary pressure) rather than spending their income on the market for produced goods and services - inducing a number of firms to cut back on the employment level (see Cencini and Rossi 2015, for analytical elaboration).

In light of this, the proper way to dispose of both inflation and unemployment is not by simply trying to influence agents' behaviour (as orthodox economists maintain), but to carry out a structural-monetary reform: the workings of our banking systems should be improved, to make them consistent with the nature of money and credit - two separate entities in the real world. In particular, banks must operate in a double-entry accounting framework that distinguishes explicitly - through two distinct book-entry departments, as originally proposed by Ricardo (1824 [1951], p. 276) for the Bank of England - the emission of money (first department) from the granting of credit (second department). Only with this structural-monetary reform will the banking system be in a position to contribute to economic growth and job creation without affecting monetary as well as financial stability negatively (see Pesenti 2016 for a recent illustration of this reform). Contrary to the so-called 'sovereign money' reform proposals - which at the time of writing are being put forward in a number of European countries - the "departmentalization' of banks' double-entry book-keeping still allows them to provide credit lines to firms as the latter need to finance production, but impedes them mechanically from issuing money in order to carry out 'non-GDP-based transactions' (Werner 2012 , p. 29) without having enough funding for them. It is therefore a halfway station between the unnecessary and potentially counter-productive 'sovereign money' reform (see Huber 2017 for a recent analytical support of this reform), on the one hand, and the disorderly workings of the current banking system, on the other.

This quantum-theoretical approach demonstrates therefore that (involuntary) unemployment is the result of a structural-monetary disorder, notable when firms' profit is invested to finance production. Owing to the banks' double-entry book-keeping, the expenditure of profits on the labour market gives rise to 'empty deposits' (Schmitt 1984), that is to say, new bank deposits to which no new output corresponds, because the latter is actually bought as soon as it is produced. If such a structural-monetary disorder would not occur, there would be no (involuntary) unemployment - hence also no natural rate of unemployment, as there is nothing really natural in (involuntary) unemployment: it is in fact a pathology of the economic system as a whole, which can be disposed of only through a structural-monetary reform (see Cencini and Rossi 2015).

\subsection{Conflict inflation and hysteresis}

Post-Keynesians have a second approach in their theoretical arsenal to undermine the concept of a natural rate of unemployment. It begins with seeing inflation as a result of conflicting claims over income between classes, namely between firms (profits) and workers (wages), and their respective bargaining powers relative to what each group considers a fair distribution of income (Dutt 1992; see also Rowthorn 1977 and Lavoie 2014). Arestis and Sawyer (2005, p. 2) summarized this approach, observing that '[a]n 
increase in the rate of inflation can be viewed as arising from some combination of the intention of some groups to increase their share of income and on enhanced opportunity to do so'.

Yet while this approach certainly does place the dynamics of inflation on the supply side rather than on the demand side, as in Friedman (1968) and most mainstream macroeconomic models, it does not necessarily negate the existence of a natural rate of unemployment. Indeed, it is still possible to generate such an equilibrium with a conflicting-claims approach to inflation where workers' wage-bargaining expectations play a dominant role. For instance, it would be possible to see labour getting more powerful as the unemployment rate falls, and as the bargaining power shifts to labour and unto wage claims, inflation can be the inevitable result as the economy is pushed beyond the 'inflation barrier'. In this sense, unemployment is seen as a way to weaken labour power, keep wage demands tame, and shift the power unto firms: 'Without sufficient unemployment, on the other hand, the conflict over relative income shares will lead to inflation' (Arestis and Skott 1993, p. 369).

So while this approach to inflation is a necessary rejection of Friedman (1968), it is not sufficient to further undermine the existence of a natural rate of unemployment. To achieve this, Post-Keynesians have to further assume the existence of hysteresis effects, whereas the 'equilibrium rate of unemployment may be a consequence of past actual rates of unemployment, and a rise in unemployment therefore may increase the equilibrium rate' (Arestis and Skott 1993, p. 365).

The presence of hysteresis suggests that as the economy moves through time, it is not converging unto a specific, independent long-run position acting as a centre of gravitation since this position itself is dependent on the current and past states of the economy and levels of aggregate demand. This suggests that this long-term position is itself unknown, and non-unique. In other words, to paraphrase Friedman, 'history' matters.

The notion of hysteresis reverses the notion of gravitation in the sense that current levels of unemployment act as a centre of gravitation of sorts on the long-term level, pulling up, in times of recession, the long-term rate. According to Gordon $(1989$, p. 220), 'NAIRU is high because actual unemployment is high, and the NAIRU can be reduced if actual unemployment declines as a result of expansionary demand policies'.

While Davidson (2006, p. 690) argues 'until the 1990s, most monetarists' arguments assumed that the natural rate of unemployment was a parametric constant that would not change over time', this was not the case for Friedman. In a sense, in his 1968 paper, Friedman was aware that the natural rate was not immutable. Rather, he explained, 'I do not mean to suggest that it is immutable and unchangeable', and proceeded to argue that supply-side factors could influence the value of this natural rate. Yet, once established, the economy would tend towards it in the long run.

This is not the same as hysteresis, of course. Friedman (1968) was arguing more in terms of 'shifting equilibrium'. Post-Keynesians, on the other hand, are clear: aggregate demand matters both in the short and the long run, and this undermines the existence of an independently determined, long-run, natural rate of unemployment. As a result, any rate of unemployment is consistent with a stable rate of inflation and, in fact, it is possible to have low rates of unemployment alongside low and stable rates of inflation.

\section{CONCLUSION}

The concept of a natural rate of unemployment has dominated the economics profession for the past five decades. This paper has shown that there are strong reasons to argue that 
the hypotheses upon which this concept is based (to wit, the exogenous supply of money and the monetary origin of inflation) are flawed and that Post-Keynesians provide a more realistic explanation of both inflation and unemployment. Moreover, coupled with the notion of hysteresis, this paper has shown the irrelevance of the concept of a natural rate of unemployment, and this carries important implications for economic policymaking.

Indeed, contrary to what both Phelps $(1967 ; 1968)$ and Friedman (1968) assume, a central bank cannot control the money supply and thereby determine its growth rate: inflation is not a 'monetary phenomenon' as suggested by Friedman (1987, p. 17). Money is endogenous and the result of banks' decision to grant credit to any (creditworthy) borrowers. Hence, provided that one is willing to abandon the neoclassical perspective propounded (among others) by Phelps (1967; 1968) and Friedman (1968), one can easily understand the total ineffectiveness of so-called 'unconventional' monetary policies that a number of central banks are carrying out, at the time of writing, to address some of the negative effects of the first systemic crisis of finance-led capitalist economies (see Rossi 2019 for further elaboration). It is not by flooding the financial sector with extraordinarily large amounts of 'liquidity' (that is, central-bank money) or by adopting a negative interest-rate policy (or both) that a central bank can contribute to eradicate the structural-monetary factors of a systemic crisis.

Further, the so-called 'fiscal consolidation' of the public sector (in fact, austerity policy) cannot but aggravate the macroeconomic performance of a country and its perspectives over the medium-to-long run, when the latter suffers from a serious and persistent lack of effective demand (Mastromatteo and Rossi 2018 elaborate on this). If those countries in the euro area that have most been suffering from the crisis continue to implement 'fiscal consolidation', their economic systems will be destroyed eventually - as a result of the recessionary dynamics induced by cutting public spending and raising the fiscal burden of the middle class in an economic framework where both the banking sector and non-financial businesses are reluctant to enter into creditor/debtor relations in order to expand production and thereby support economic growth. As Samuelson (cited by Tobin 1980, p. 37) famously observed, economists have two eyes, notably, one for demand and the other for supply.

Let us hope that this paper has contributed to opening both eyes of those economists who still believe in 'supply-side economics' à la Phelps $(1967 ; 1968)$ and Friedman (1968). The world and its actually existing macroeconomic problems need a systemic understanding of how our economic system works. One needs therefore to keep both eyes wide open when analysing any macroeconomic issue, to be able to consider the economic system as a whole (Keynes 1936). In the contrary case, to wit, when only the supply side (or the demand side) of the economy is considered, one can expect that a systemic crisis will occur sooner or later - as it did occur as a result of those economic policy interventions that focused only on some parts of the economic system (such as the financial sector) instead of looking at (and taking care of) the economy as a whole.

\section{REFERENCES}

American Economic Review (2011), '100 years of the American Economic Review: the top 20 articles', 101(1), 1-8.

Arestis, P. and M. Sawyer (2005), 'Aggregate demand, conflict and capacity in the inflationary process', Cambridge Journal of Economics, 29(6), 959-974. 
Arestis, P. and P. Skott (1993), 'Conflict, wage determination, and hysteresis in U.K. wage determination', Journal of Post Keynesian Economics, 15(3), 365-386.

Bailly, J.-L., A. Cencini and S. Rossi (eds) (2017), Quantum Macroeconomics: The Legacy of Bernard Schmitt, London and New York: Routledge.

Cencini, A. and S. Rossi (2015), Economic and Financial Crises: A New Macroeconomic Analysis, Basingstoke, UK and New York: Palgrave Macmillan.

Cencini, A. and S. Rossi (2016), 'Inflation and unemployment', in L.-P. Rochon and S. Rossi (eds), An Introduction to Macroeconomics: A Heterodox Approach to Economic Analysis, Cheltenham, UK and Northampton, MA: Edward Elgar Publishing, pp. 172-192.

Davidson, P. (2006), 'Can, or should, a central bank inflation target?', Journal of Post Keynesian Economics, 28(4), 689-703.

Dutt, A.K. (1992), 'Conflict inflation, distribution, cyclical accumulation and crises', European Journal of Political Economy, 8(4), 579-597.

Forder, J. (2010), 'The historical place of the "Friedman-Phelps" expectations critique', European Journal of the History of Economic Thought, 17(3), 493-511.

Forder, J. (2018), 'What was the message of Friedman's Presidential address to the American Economic Association?', Cambridge Journal of Economics, 42(2), 523-541.

Friedman, M. (1968), 'The role of monetary policy', American Economic Review, 58(1), 1-17.

Friedman, M. (1972), 'Comments on the critics', Journal of Political Economy, 80(5), 906-950.

Friedman, M. (1987), 'Quantity theory of money', in J. Eatwell, M. Milgate and P. Newman (eds), The New Palgrave: A Dictionary of Economics, vol. IV, London and Basingstoke: Macmillan, pp. 3-20.

Friedman, M. and R.D. Friedman (1998), Two Lucky People, Chicago: University of Chicago Press.

Gordon, R.J. (1989), 'Hysteresis in history: was there ever a Phillips curve?', American Economic Review, 79(2), 220-225.

Graziani, A. (2003), The Monetary Theory of Production, Cambridge, UK: Cambridge University Press.

Huber, J. (2017), Sovereign Money: Beyond Reserve Banking, Basingstoke, UK and New York: Palgrave Macmillan.

Keynes J.M. (1936), The General Theory of Employment, Interest and Money, London: Macmillan.

Lavoie, M. (2004), 'The New Consensus on monetary policy seen from a post-Keynesian perspective', in M. Lavoie and M. Seccarrecia (eds), Central Banking in the Modern World: Alternative Perspectives, Cheltenham, UK and Northampton, MA: Edward Elgar Publishing, pp. $15-34$.

Lavoie, M. (2014), Post-Keynesian Economics: New Foundations, Cheltenham, UK and Northampton, MA: Edward Elgar Publishing.

Mastromatteo, G. and S. Rossi (2018), 'The mirage of expansionary "fiscal consolidation" to resolve the euro-area crisis', in K. Power, E. Lebduskova and T. Ali (eds), Discourse Analysis and Austerity: Critical Studies from Economics and Linguistics, London and New York: Routledge, forthcoming.

Moore, B.J. (1988), Horizontalists and Verticalists: The Macroeconomics of Credit Money, Cambridge, UK: Cambridge University Press.

Pesenti, A. (2016), 'The meaning of monetary stability', Faculty of Economics and Social Sciences Working Paper, No 475, University of Fribourg, Switzerland.

Phelps, E.S. (1967), 'Phillips curves, expectations of inflation and optimal unemployment over time', Economica, 34(135), 254-281.

Phelps, E.S. (1968), 'Money-wage dynamics and labor-market equilibrium', Journal of Political Economy, 76(4), 678-711.

Phillips, A.W. (1958), 'The relation between unemployment and the rate of change of money wage rates in the United Kingdom, 1861-1957', Economica, 25(100), 283-299.

Ricardo, D. (1824 [1951]), Plan for the Establishment of a National Bank, in P. Sraffa and M.H. Dobb (eds), The Works and Correspondence of David Ricardo, vol. IV: Pamphlets and Papers 1815-1823, Cambridge, UK: Cambridge University Press, pp. 276-300. 
544 Review of Keynesian Economics, Vol. 6 No. 4

Rossi, S. (2015), 'Structural reforms in payment systems to avoid another systemic crisis', Review of Keynesian Economics, 3(2), 213-225.

Rossi, S. (2018), 'Milton Friedman and the monetarist school', in H. Bougrine and L.-P. Rochon (eds), A Short History of Economic Thought: Major Contributions since Adam Smith, Cheltenham, UK and Northampton, MA: Edward Elgar Publishing, forthcoming.

Rossi, S. (2019), 'The dangerous ineffectiveness of negative interest rates: the case of Switzerland', Review of Keynesian Economics, 7(2), forthcoming.

Rowthorn, R.E. (1977), 'Conflict, inflation and money', Cambridge Journal of Economics, 1(3), 215-239.

Schmitt, B. (1984), Inflation, chômage et malformations du capital: macroéconomie quantique, Paris and Albeuve: Economica and Castella.

Thirlwall, A.P. (2018), 'A life in economics', PSL Quarterly Review, 71(284), 9-39.

Tobin, J. (1980), 'Stabilization policy ten years after', Brookings Papers on Economic Activity, 11(1), 19-71.

Werner, R. (2012), 'Economics as if banks mattered: a contribution based on the inductive methodology', The Manchester School, 79(2), 25-35. 